\title{
Isolation, characterisation and continuous culture of Lactobacillus spp. and its potential use for lactic acid production from whey
}

\author{
Carlos Eduardo MEJIA-GOMEZ ${ }^{1}$, Norman BALCÁZAR ${ }^{2 *}$ (i)
}

\begin{abstract}
Bioprospecting of microorganisms with the potential of exploiting agro-industrial wastes is an active field of biotechnological research. In this study, we aimed to isolate a microorganism adapted to the dairy matrix with specific characteristics to produce lactic acid from dairy industry wastes, such as whey. Whey was collected from the agricultural region of Antioquia, Colombia, and samples were cultured on Man-Rogosa-Sharpe modified medium using lactose as a source of carbon. The most promising strain isolated was characterised, and its adaptation to whey was determined. A gram-positive Lactobacillus was isolated and named as G1. This strain grows in deproteinised whey with low protein requirements, has a homofermentative metabolism and exhibits high tolerance to low $\mathrm{pH}(\leq 5.0)$. The G1 strain is a promising bacterium for use in lactic acid production from whey, which is an underutilised by-product of the dairy industry.
\end{abstract}

Keywords: lactic acid bacteria; lactic acid; whey; bioprospecting; growth kinetics.

Practical Application: Whey is a dairy waste produced during cheese production; it is liquid whose main component is lactose, which accounts for $90 \%$ of its organic content. Such wastes are highly polluting. In this study, a native lactobacilli strain was isolated, that efficiently converts whey into lactic acid. This promising strain could become a viable option for the treatment of dairy industry residues, while not only meeting the disposal requirements but also increasing profits with lactic acid as a by-product.

\section{Introduction}

Lactobacillus is a genus of highly heterogeneous microorganisms and is the largest genus of lactic acid (LA) bacteria (LAB), with approximately 67 species identified to date (Stiles \& Holzapfel, 1997). They are facultative anaerobic, gram-positive, catalase-negative, non-motile, non-spore-forming bacilli with a $\mathrm{G}+\mathrm{C}$ content of 33\%-55\% mol (Axelsson, 2004). Lactobacilli have numerous industrial applications, including as probiotic and LA production. LA has multiple applications in the food, pharmaceutical and chemical industries, where there is a great demand for poly-L-LA production, a biodegradable polymer (Kozlovskiy et al., 2017). To meet this market demand, approximately $90 \%$ of LA is produced using biotechnological (fermentative) approaches wherein LA is obtained as a product of microbial metabolism, the remaining $10 \%$ of LA is produced by a chemical method (Alves de Oliveira et al. 2018). However, biotechnological processes are preferred because the chemical approach includes many issues due to contamination and requires extreme process conditions (Wang et al., 2015).

However, for commercial competitiveness, the fermentation approach must utilise a microorganism that produces at least $100 \mathrm{~g} \mathrm{l}^{-1}$ of LA in an economic culture media (e.g. agro-industrial wastes) (Abdel-Rahman et al., 2013). At present, it is estimated that the annual world demand for LA is approximately 291,300 metric tonnes (Grand View Research, 2017).
Lactobacilli are classified as homofermentative, facultative heterofermentative or obligate heterofermentative based on their metabolism (Gänzle, 2015). Homofermentative lactobacilli exclusively produce LA as the end product of hexose metabolism via the Embden-Meyerhof-Parnas pathway.

Lactobacilli are found in several ecological niches and can adapt to various environments, including human oral and vaginal cavities; fermented food; soil and dairy industry by-products, such as whey. Whey is a dairy waste produced during cheese production; it is a greenish liquid whose main component is lactose, present at a concentration of $45-50 \mathrm{~g} \mathrm{l}^{-1}$, which accounts for $90 \%$ of its organic content. Fats and proteins also contribute to its organic content, with concentration ranging from 4.0 to $5.0 \mathrm{~g} \mathrm{l}^{-1}$ and 6.0 to $8.0 \mathrm{~g} \mathrm{l}^{-1}$, respectively (You et al., 2017). Such wastes can result in chemical oxygen demand of up to $60,000 \mathrm{mg} \mathrm{O}_{2} 1^{-1}$; therefore, they cannot be discarded into local drainage systems without prior treatment (González et al., 2007). The current total production of whey is about 180 to 190 million tons/year in the world and only $50 \%$ is processed becoming a problem of environmental pollution (Mollea et al., 2013).

The growth kinetics of microorganisms is evaluated using batch systems because these are easy to handle and monocultures free from microbial contamination can be maintained. Lactobacillus growth can be adjusted to an autocatalytic reaction model 
(Equation 1) wherein cells formed $\left(\mathrm{X}, \mathrm{g}^{-1}\right)$ at a specific time $(\mathrm{t})$ are proportional to the cell concentration and specific growth rate $\left(\mu, h^{-1}\right)$.

$\frac{d X}{d t}=\mu X$

The substrate consumed in this case is lactose from whey and can be determined using Equation 2, where $\mathrm{Y}_{\mathrm{X} / \mathrm{S}}$ are cells (in $\mathrm{g}$ ) produced per gram of substrate $(\mathrm{S})$ consumed.

$-r_{S}=\frac{d S}{d T}=-\mu \frac{X}{Y_{X / S}}$

The relationship between the substrate $(S)$ and specific growth rate is provided by an empirical equation described by Monod in 1949 (Equation 3) that has two constant values, the maximum specific growth rate $\left(\mu_{\max }, h^{-1}\right)$ and saturation constant $\left(\mathrm{K}_{\mathrm{S}}, \mathrm{g} \mathrm{l}^{-1}\right)$ (Monod, 1949).

$\mu=\frac{\mu_{\max S}}{K_{S}+S}$

Finally, LA production can be described in terms of microbial growth using Equation 4, where $\mathrm{P}$ is the concentration of the product, $\alpha$ is the growth-associated product formation and $\beta$ is the non-growth-associated product formation (Luedeking \& Piret, 1959).

$r_{P}=\frac{d P}{d t}=\alpha \mu X+\beta X$

The aim of the present study was to isolate a Lactobacillus strain adapted to grow in whey with a strong potential to produce LA. Thus, in the near future, this microorganism will contribute to reducing the organic burden generated by whey disposal. It will also contribute to establishing a biotechnological platform for industrial LA production.

\section{Materials and methods}

This article does not contain any studies with human participants or animals performed by any of the authors.

\subsection{Microorganism isolation}

Whey samples were collected from a dairy located at the Low Cauca agricultural region of Antioquia, Colombia, and stored in a cold condition during transportation in sterile containers. One millilitre of whey was diluted in $9 \mathrm{ml}$ of Lactobacillus Man-Rogosa-Sharpe modified medium [MRSM; containing $20 \mathrm{~g} \mathrm{l}^{-1}$ lactose, $10 \mathrm{~g} \mathrm{l}^{-1}$ peptone, $8 \mathrm{~g} \mathrm{l}^{-1}$ meat extract, $4 \mathrm{~g} \mathrm{l}^{-1}$ yeast extract (YE), $2 \mathrm{~g} \mathrm{l}^{-1} \mathrm{~K}_{2} \mathrm{HPO}_{4}, 5 \mathrm{~g} \mathrm{l}^{-1}$ sodium acetate trihydrate, $2 \mathrm{~g} \mathrm{l}^{-1}$ triammonium citrate, $0.2 \mathrm{~g} \mathrm{l}^{-1}$ magnesium sulphate heptahydrate and $0.05 \mathrm{~g} \mathrm{l}^{-1}$ magnesium sulphate tetrahydrate]; all salts and lactose were procured from Merk ${ }^{\mathrm{TM}}$ (Darmstadt, Germany), whereas YE, peptone and meat extract were procured from Oxoid ${ }^{\mathrm{TM}}$ (Cambridge, UK). After 48-h growth in the liquid medium at $37^{\circ} \mathrm{C}$, the sample was seeded into solid MRSM medium, and isolated colonies were selected for growth in a liquid MRSM medium. The isolated strains were tested by Gram staining with a catalase assay that detects the presence of enzymes that degrade hydrogen peroxide and a motility test in sulphide indole motility medium (Garrity et al., 2001). We selected isolates with a bacillary morphology, and which were gram positive, catalase negative, non-motile and homofermentative (Zuñiga et al., 1993). The latter was verified by seeding in a Durham hood in MRSM medium; strains were considered homofermentative if gas had not accumulated in the hood.

\subsection{LA production by the selected strain}

From each selected strain, one colony was seeded in $10 \mathrm{ml}$ of MRSM medium ( $\mathrm{pH} 6.0 \pm 0.2$ ) and incubated overnight at $35{ }^{\circ} \mathrm{C}$. One millilitre of this culture was inoculated into a $100 \mathrm{ml}$ flask containing $50 \mathrm{ml}$ of sterile MRSM medium and incubated at $35^{\circ} \mathrm{C}$ with shaking at $150 \mathrm{rpm}$ for $48 \mathrm{~h}$. At the end of incubation, LA and lactose concentrations in the samples were determined.

\subsection{Biochemical identification of the selected strain}

Preliminary testing was conducted using an API $50 \mathrm{CHL}$ medium (Biomerieux, Durham, NC, USA) for identifying the Lactobacillus species; only the selected strain was evaluated for maximum LA production. During incubation, catabolism of various carbohydrates (48 different sources of carbon) leads to the formation of organic acids, which cause a change in the colour of the $\mathrm{pH}$ indicator. The resulting biochemical profile facilitates the identification of Lactobacillus.

\subsection{Optimisation of LAB growth conditions.}

The strain identified to produce the highest amount of LA was selected for conducting a study to optimise LAB growth conditions. The experimental design was based on a complete response surface analysis and developed using the Design Expert ${ }^{\circledR} 5.0$ software. The evaluated factors and their respective levels were as follows (indicated as factor level -1 , level 0 and level 1): agitation rate, 50, 100 and $150 \mathrm{rpm}$; $\mathrm{pH}, 5.0,6.0$ and 7.0 and temperature: $30^{\circ} \mathrm{C}, 33^{\circ} \mathrm{C}$ and $40^{\circ} \mathrm{C}$. Twenty-seven experiments were generated from response surface analysis, and five replicates of each were performed for assessing experimental error. The medium used was MRSM medium, and the optimum growth conditions were those that resulted in the highest LA production.

\subsection{Carbon:Nitrogen ratio (C:N)}

To evaluate the minimum nutritional requirements that might improve the efficiency of LA production by the selected strain, we proceeded to evaluate the C:N ratio. Based on the $\mathrm{C}: \mathrm{N}$ ratio of MRSM medium, the ratio was arbitrarily fixed at 1:1. The C:N ratios used were 3:1, 5:1, 8:1 and 10:1, which were obtained by maintaining the concentration of the carbon source constant at $20 \mathrm{~g} \mathrm{l}^{-1}$ and varying the nitrogen sources (i.e. peptone, meat and YE). Assays were performed under the optimum growth conditions found for the selected strain, and as a dependent variable, substrate conversion (carbon source) was assessed after 48 -h fermentation using the following equation: 
$\mathrm{X}=\left(\mathrm{S}_{0}-\mathrm{S}\right) / \mathrm{S}_{0} \times 100$ (Bailey \& Ollis, 1986), where $\mathrm{S}_{0}$ is the initial concentration of lactose and $S$ is the concentration after 48-h fermentation.

\subsection{Adaptation of the selected strain to whey}

Inhibition of Lactobacillus growth by $\mathrm{pH}$ has been reported in the literature (Adamberg et al., 2003), and pH is known to decrease as LA production increases. To avoid these inhibitory effects, we evaluated the minimum requirement for calcium carbonate $\left(\mathrm{CaCO}_{3} ; 0,5,10\right.$ and $\left.15 \mathrm{~g} \mathrm{l}^{-1}\right)$ as a $\mathrm{pH}$-regulating agent in MRSM medium containing $50 \mathrm{~g} \mathrm{l}^{-1}$ of lactose at the identified C:N ratio.

Whey was pre-treated by sterilisation at $98^{\circ} \mathrm{C}$ for $20 \mathrm{~min}$, and the insoluble material was pelleted by centrifugation at $8,000 \mathrm{~g}$ for $10 \mathrm{~min}$. The supernatant was collected and passed through gauze to remove low-density insoluble matter. This whey was supplemented with $\mathrm{YE}$ at concentrations of $0.2 \%, 0.4 \%, 0.8 \%$ and $1.0 \%(\mathrm{~W} / \mathrm{W})$ to ensure minimum nutritional requirements.

\subsection{Growth kinetics, substrate consumption and product formation}

Studies on growth, lactose consumption and LA production by the selected strain were conducted using a RALF ${ }^{\mathrm{TM}} 3.71$ Bioengineering bioreactor with a 2 -1 work volume in pre-treated whey medium supplemented with YE and sterilised at $98^{\circ} \mathrm{C}$ for $20 \mathrm{~min}$. The experiments were performed under the optimum growth conditions identified earlier. The conditions in the bioreactor were maintained constant using $5 \mathrm{~mol} \mathrm{l}^{-1} \mathrm{NaOH}$ solution to control $\mathrm{pH}$ as well as water recirculation and agitation to regulate the temperature. Fermentation was performed for $48 \mathrm{~h}$. Samples were collected every $2 \mathrm{~h}$ during the first $12 \mathrm{~h}$ and every $6 \mathrm{~h}$ after $24 \mathrm{~h}$.

\subsection{Continuous culture system}

Four assemblies were prepared with dilution rates of $0.05,0.08$, 0.125 and $0.20 \mathrm{~h}^{-1}$ at $1.7,2.7,4.2$ - and $6.7-\mathrm{mL} \mathrm{min}^{-1}$, respectively, in the Bioengineering ${ }^{\mathrm{TM}}$ bioreactor with an effective volume of 21 with the parameters adjusted according to the batch system. To stabilise the continuous system, 8-10 l of culture medium was passed through the bioreactor, and a sample was used for further analysis.

\subsection{Analytical methods}

LA and lactose were measured using high-performance liquid chromatography (HPLC) on an Agilent ${ }^{\circledR} 1200$ instrument equipped with a refractive index detector. Chromatography was performed using a Biorad ${ }^{\circledR} \mathrm{HPX} 87 \mathrm{H}$ ion exchange column at $35^{\circ} \mathrm{C}$ using a $5 \mathrm{mmol} \mathrm{l}^{-1} \mathrm{H}_{2} \mathrm{SO}_{4}$ solution as the mobile phase at a flow rate of $0.6 \mathrm{ml} \mathrm{min}^{-1}$. BioUltra ${ }^{\circledR}$ lactose was supplied by Sigma (St. Louis, MO, USA), 88\% LA (w/w) by Carlo Erba (Sabadell, Barcelona, Spain) and $98 \% \mathrm{H}_{2} \mathrm{SO}_{4}(\mathrm{w} / \mathrm{w})$ by Mallinckrodt (St. Louis, MO, USA). For the creation of a standard curve, samples were centrifuged at $8000 \mathrm{~g}$ for $5 \mathrm{~min}$. Then, the supernatant was diluted with the mobile phase (1:10, supernatant: mobile phase) and filtered using a $0.22-\mu \mathrm{m}$ filter prior to injection. Biomass quantification was conducted using a Genesys ${ }^{\circledR} 2 \mathrm{PC}$ spectrophotometer at a wavelength of $600 \mathrm{~nm}$ using samples diluted at a ratio of 1:20 in water and a biomass factor of $0.35 \mathrm{~g} \mathrm{l}^{-1}$ for each optical density unit. Statistical analyses were focused on differences in mean values.

\section{Results}

\subsection{Isolation of microorganisms and their biochemical identification}

A total of 17 strains were isolated from 5 whey samples; of these, 1 was isolated from a sample of serum atollabuey (termed as suero costeño in Spanish) and several others were obtained from the specimen bank of the Biotransformation Group at the University of Antioquia. These strains showed satisfactory growth in MRSM medium containing lactose as a source of carbohydrates. Based on the inclusion criteria described above (i.e. gram positive, catalase negative, non-motile, rod shape and homofermentative), 7 strains were selected for further study (Table 1).

\section{LA production}

G1, MA7 and MA8 strains showed the highest LA production among the 7 selected strains (Figure 1); in fact, morphological and biochemical analyses demonstrated that MA7 and MA8 strains were the same. Because the aim of this study was to maximise LA production from dairy industry wastes, the G1 strain was selected for further studies because it produced fewer cells than MA7 and MA8 strains (data not shown).

Table 1. Description of selected lactobacilli strains.

\begin{tabular}{cll}
\hline Strain & \multicolumn{1}{c}{ Source } & Morphological description \\
\hline SL3-1 & Arcoiris dairy company ${ }^{\mathrm{a}}$, Medellín & Short bacilli \\
G1 & Atollabuey whey (Suero costeño) ${ }^{\mathrm{b}}$, Lower Cauca region & Shain grouped bacilli \\
MA4 & Biotransformation group's bacterial collection & Bacilli \\
G81 & Atollabuey whey (Suero costeño) ${ }^{\mathrm{b}}$, Lower Cauca region & Short aggregated bacilli \\
MA7 & Biotransformation group's bacterial collection & Short bacilli \\
MA8 & Biotransformation group's bacterial collection & Non-aggregated bacilli \\
KF1 & Biotransformation group's bacterial collection &
\end{tabular}

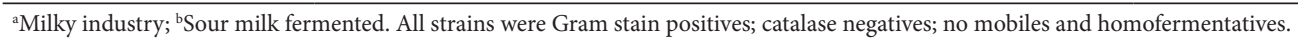




\section{Biochemical identification of the G1 strain}

The initial biochemical identification of the G1 strain using the Biomeraux API CHL- $50{ }^{\circledR}$ kit showed that there was a $95 \%$ likelihood that this strain is a Lactobacillus paracasei

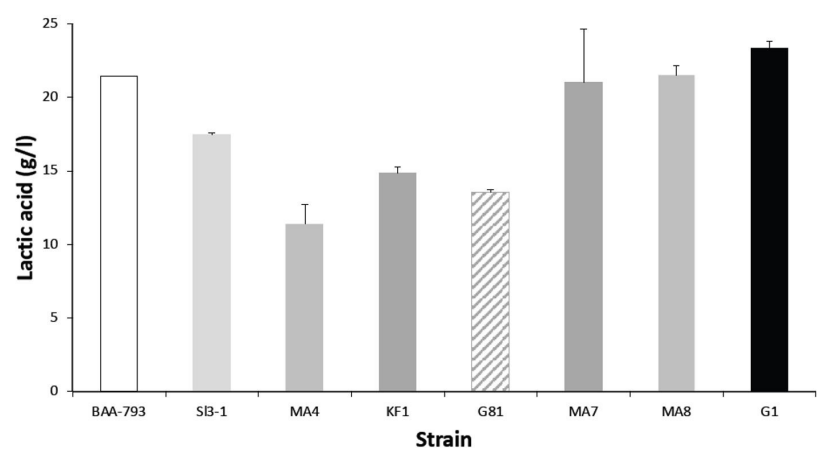

Figure 1. Acid lactic production by the selected strain. Strains were cultivated in Man-Rogosa-Sharpe modified medium, in which glucose was substituted with $20 \mathrm{~g} \mathrm{l}^{-1}$ of lactose, for $48 \mathrm{~h}$, and LA concentration in the supernatant was determined by high-performance liquid chromatography. Control strain, Lactobacillus plantarum (strain ATCC BAA-793). Values are presented as mean \pm SD $(n=3)$. Table 1 summarises the description of the strains. paracasei strain. HPLC analysis showed that the G1 strain was a homofermentative strain because it exclusively produced LA from lactose present in the medium (data not shown).

\subsection{Optimisation of growth conditions for the G1 strain}

Growth was maximum at a $\mathrm{pH}$ of approximately 6.0 , a temperature of $34^{\circ} \mathrm{C}$ and an agitation rate of $100 \mathrm{rpm}$ (Figure 2A), which are typical conditions for bacteria belonging to the genus Lactobacillus.

\section{Ideal C:N ratio for the G1 strain}

One of the major factors limiting microorganism growth is nutritional constraint in culture media, particularly the protein/nitrogen source, which is peptone, meat and YE in MRSM medium. These protein requirements increase the cost of culture media, thereby reducing the economic feasibility of industrial LA production. Therefore, evaluation of the protein concentration of the protein source in the medium was performed by studying the effects of changes in the $\mathrm{C}: \mathrm{N}$ ratio on the growth of the G1 strain using substrate conversion as the dependent variable, which is indicative of the transformation of lactose to LA because LA is the main metabolite of its catabolism. Nitrogen use was minimised a)

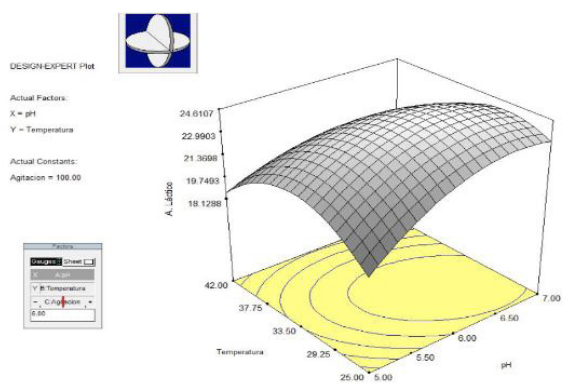

c)

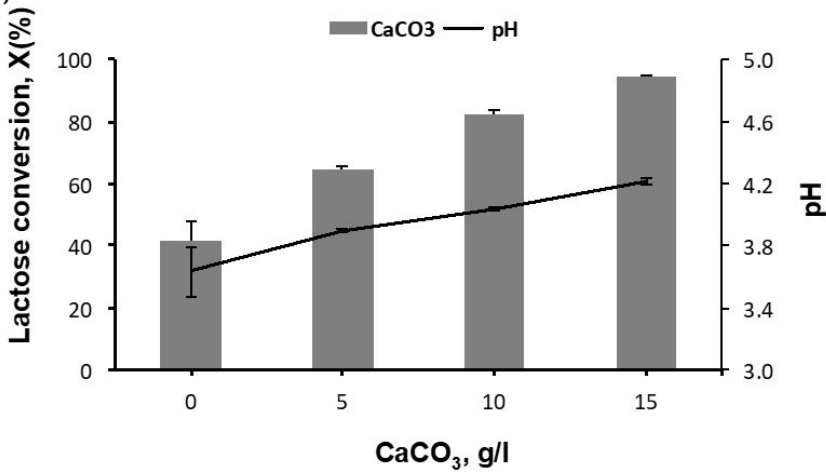

b)

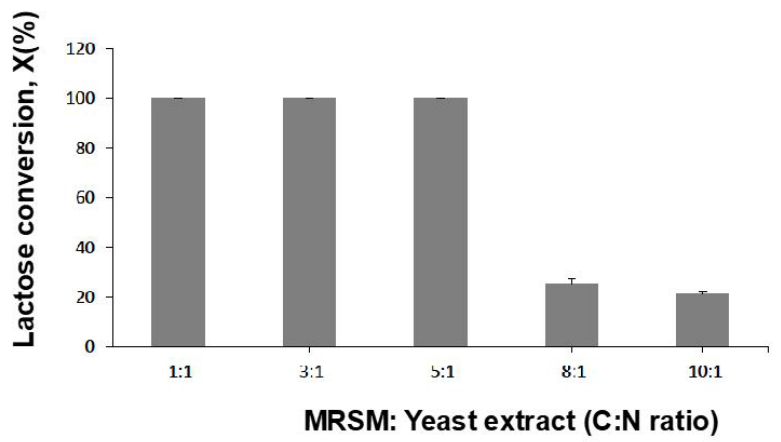

d)

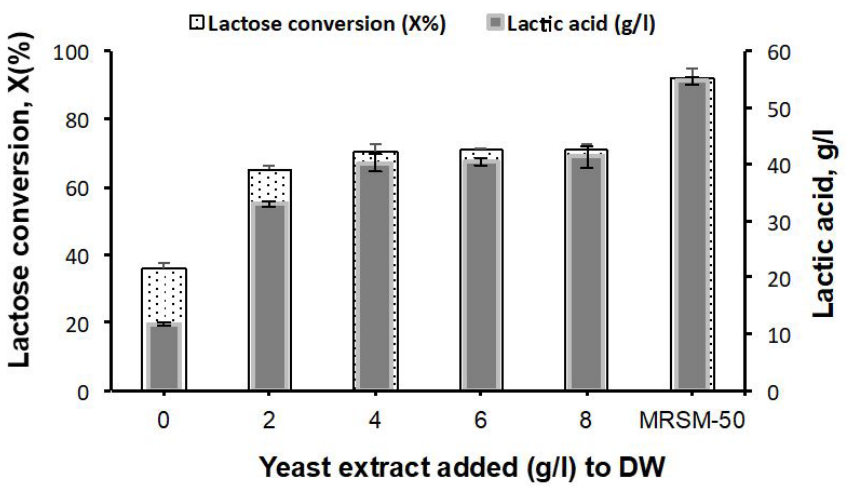

Figure 2. Determination of the optimum growth condition for the G1 strain. (a) Response surface methodology for optimisation of G1 growth parameters in MRSM medium supplemented with $20 \mathrm{~g} \mathrm{l}^{-1}$ of lactose; (b) Nitrogen as a limiting factor in the conversion of lactose to lactic acid. $\mathrm{X}(\%)=\left[\left(\mathrm{S}_{0}-\mathrm{S}\right) / \mathrm{S}_{0}\right] \times 100$, where $\mathrm{S}_{0}$ is the initial concentration of lactose $\left(\mathrm{g} \mathrm{l}^{-1}\right)$ and $\mathrm{S}$ is its final concentration $\left(\mathrm{g} \mathrm{l}^{-1}\right)$ after 48-h fermentation; (c) Effect of supplementation of calcium carbonate $\left(\mathrm{CaCO}_{3}\right)$ to MRSM medium. MRSM-50: Man-Rogosa-Sharpe modified (MRSM) medium supplemented with $50 \mathrm{~g} \mathrm{l}^{-1}$ of lactose; $\mathrm{pH}$ was measured after 48 -h fermentation; (d) Effect of supplementing deproteinised whey with yeast extract. S: initial concentration of lactose (47.8 $\left.\mathrm{g} \mathrm{l}^{-1}\right)$; MRSM-50: MRSM medium supplemented with $50 \mathrm{~g} \mathrm{l}^{-1}$ of lactose and $10 \mathrm{~g} \mathrm{l}^{-1}$ of CaCO. Values are presented as mean $\pm \mathrm{SD}(\mathrm{n}=3)$. 
without altering the conversion of lactose to $\mathrm{LA}$ at a $\mathrm{C}: \mathrm{N}$ ratio of 5:1, whereas LA production drastically reduced at higher ratios (8:1 and 10:1), indicating that the limiting substrate is the nitrogen source (Figure 2B). There was no evidence of substrate/product inhibition in LA production when lactose was used at a concentration of $20 \mathrm{~g} \mathrm{l}^{-1}$.

\subsection{Adapting the G1 strain to whey}

Whey contains a lactose concentration of approximately $50 \mathrm{gl}^{-1}$, as determined by HPLC. This concentration of lactose can limit LA production because of a decrease in $\mathrm{pH}$. To eliminate drastic $\mathrm{pH}$ decreases, a buffering agent such as $\mathrm{CaCO}_{3}$ is required. In the absence of a carbonate, $40 \%$ of the lactose was converted; indicating that $\mathrm{pH} 3.5$ reached at the end of the 48-h fermentation may inhibit the conversion of lactose to LA. When $15 \mathrm{gl}^{-1}$ of $\mathrm{CaCO}_{3}$ was added, $90 \%$ lactose was converted to LA after 48-h fermentation (Figure 2C).

The adaptation of the G1 strain to whey began with an initial treatment to eliminate insoluble solids. Whey was sterilised at $98^{\circ} \mathrm{C}$ for $20 \mathrm{~min}$ and then centrifuged at $8000 \mathrm{~g}$ for $10 \mathrm{~min}$. The supernatant was designated as deproteinised whey (DW), had a lactose concentration of $47.8 \mathrm{~g} \mathrm{l}^{-1}$ and was used as a substrate for LA production. Low consumption of lactose was observed when DW was used alone (36\% conversion, Figure 2D), possibly due to the lack of a nitrogen source. Therefore, DW was supplemented with different concentrations of YE.

DW medium appeared to contain nitrogen sources that minimise the need for additional nitrogen, but supplementation was necessary because DW did not contain enough protein to sustain efficient conversion of lactose to LA (Figure 2D).

\subsection{Growth kinetics, substrate consumption and product formation by the G1 strain in DW medium supplemented with $4 \mathrm{gl}^{-1}$ of $Y E$}

The G1 strain exhibited slower growth in DW medium than in MRSM-50 medium (Figure 3A). This is reflected by a delayed entry into the exponential phase $(20 \mathrm{~h})$ in DW medium compared with that in MRSM-50 medium (8-10 h). This could be due to the presence of compounds in DW medium that retard bacterial growth; however, after 48 -h growth in DW medium, biomass production values were comparable to those in MRSM-50 medium (i.e. approximately $2.5 \mathrm{~g} \mathrm{l}^{-1}$ ).

From Equation 1, for calculating the specific growth rate, $\mu_{\max }$ in MRSM-50 medium was $0.23 \mathrm{~h}^{-1}$ and that in DW medium was $0.19 \mathrm{~h}^{-1}$. These values were obtained in the exponential growth phase, indicating that DW is more difficult to assimilate than MRSM-50.

Although whey has not been characterised as an easily assimilable substrate for microorganisms, in this study, grams of LA per gram of lactose supplied $\left(\mathrm{Y}_{\mathrm{LA} / \mathrm{Tot}} ; \mathrm{g} \mathrm{g}^{-1}\right)$ of 0.25 was attained for whey without any pre-treatments, 0.84 in DW medium supplemented with $4 \mathrm{~g} \mathrm{l}^{-1}$ of YE and 1.1 in MRSM-50 medium (Figure 2D). Analysis of the kinetics in the bioreactor and maintenance of $\mathrm{pH}$ at 6.0 achieved an $\mathrm{Y}_{\mathrm{LA} / \mathrm{Tot}}$ of $1.1 \mathrm{~g} \mathrm{~g}^{-1}$ (Figure 3B), demonstrating that growth inhibition is caused due to the $\mathrm{pH}$ of $\mathrm{DW}$ medium supplemented with $\mathrm{YE}$ and without the addition of $\mathrm{CaCO}_{3}$ to act as a neutralising agent.
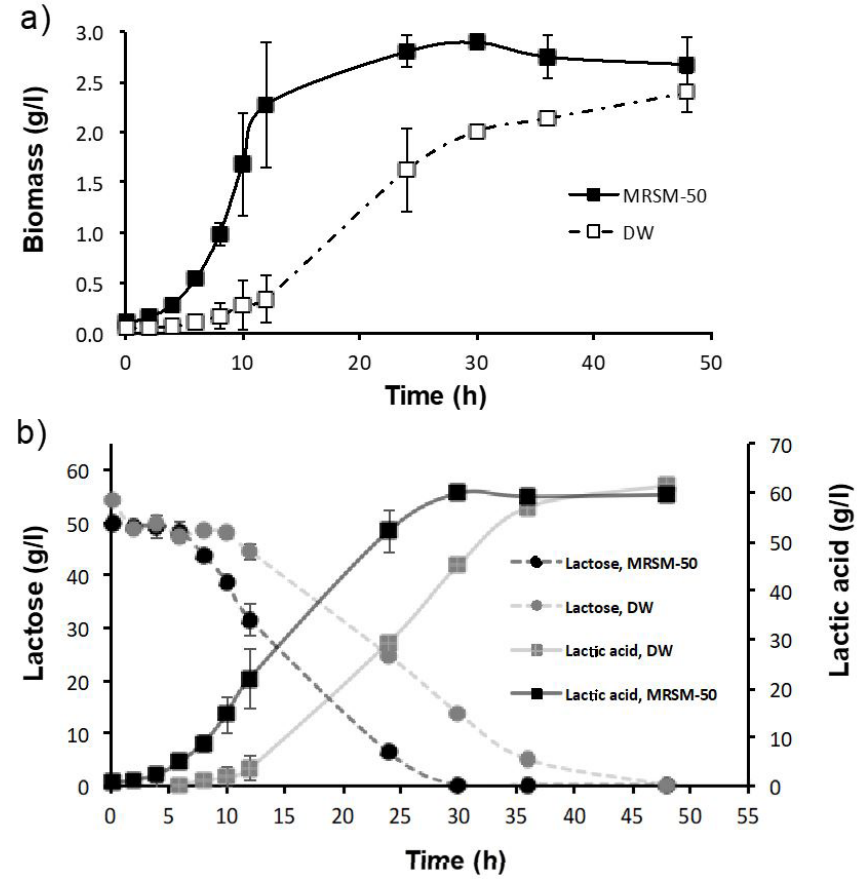

Figure 3. (a) Growth kinetics and (b) Substrate consumption kinetics and product formation by the G1 strain in DW and MRSM-50 media. DW: deproteinised whey supplemented with $4 \mathrm{~g} \mathrm{l}^{-1}$ of yeast extract. MRSM-50: MRSM medium supplemented with $50 \mathrm{~g} \mathrm{l}^{-1}$ of lactose and $10 \mathrm{~g} \mathrm{l}^{-1}$ of calcium carbonate $(\mathrm{C}: \mathrm{N}=5: 1)$. The experiment was performed in the RALF ${ }^{\mathrm{TM}}$ 3.7 L Bioengineering bioreactor, and $2 \mathrm{~mL}$ aliquots were taken at different time points for lactose, lactic acid and biomass determination. Values are presented as mean $\pm \operatorname{SD}(n=3)$.

Table 2. Results in continuous system for the G1 strain.

\begin{tabular}{lcccc}
\hline $\mathrm{D}\left(\mathrm{h}^{-1}\right)$ & $\begin{array}{c}\mathrm{S} \text { (lactose) } \\
\mathrm{g} \mathrm{l}^{-1}\end{array}$ & $\begin{array}{c}\mathrm{X} \text { (biomass) } \\
\mathrm{g} \mathrm{l}^{-1}\end{array}$ & $\begin{array}{c}\mathrm{P}(\mathrm{LA}) \\
\mathrm{g} \mathrm{l}^{-1}\end{array}$ & $\begin{array}{c}\text { Productivity } \\
\mathrm{g} \mathrm{l}^{-1} \mathrm{~h}^{-1}\end{array}$ \\
\hline 0.05 & 13.44 & & 41.73 & 2.1 \\
0.08 & 20.96 & 1.2 & 32.12 & 2.6 \\
0.125 & 26.45 & 8.07 & 22.92 & 2.9 \\
0.2 & 40.35 & 0.92 & 8.64 & 1.73 \\
\hline
\end{tabular}

D: dilution; S: substrate consumed; X: cells formed; LA: lactic acid.

\subsection{Continuous culture system}

At a low dilution rate of $0.125 \mathrm{~h}^{-1}$, high LA productivity $\left(2.9 \mathrm{~g} \mathrm{l}^{-1} \mathrm{~h}^{-1}\right)$ was observed, whereas at higher dilution rates, LA productivity decreased because of the low conversion of lactose inside the system resulting from the low retention time (Table 2). However, LA productivity increased by $100 \%$ compared with that observed in the batch system $\left(1.46 \mathrm{~g} \mathrm{l}^{-1} \mathrm{~h}^{-1}\right)$.

\section{Discussion}

The strategy of microorganism isolation from different environments or samples is diverse and has a specific objective of increasing agro-industrial material bioconversion to obtain LA. Abdel-Rahman et al. (2013) isolated 631 bacteria from 30 environmental samples and identified the strain Enterococcus mundtii QU 25 as a promising strain for conversion of cellobiose 
to LA. In the present study, although 17 microorganisms were isolated from whey, only the G1 strain fulfilled the objective of isolating a promising strain for lactose conversion to LA.

LA production (23.33 $\mathrm{g} \mathrm{l}^{-1}$; Figure 1) by the G1 strain from lactose in MRSM medium reached a yield ( $\mathrm{g}$ of product per

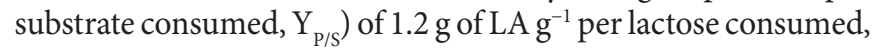
which is the normal value for LAB because of their ability to use amino acids for growth (De Giori et al., 1985).

After finding the adequate nitrogen source concentration (YE in the present study), the objective was to guaranty total lactose conversion. Assessment of $\mathrm{C}: \mathrm{N}$ ratios showed that at ratios of $1: 1,3: 1$ and 5:1, lactose conversion was $100 \%$, whereas at ratios of $8: 1$ and 10:1, lactose conversion drastically decreased (20\%), demonstrating the limiting nature of the nitrogen source. Thus, 5:1 was selected as the optimum ratio because it minimised YE requirements for culture media. At a lactose concentration of $20 \mathrm{gl}^{-1}$, there was no observable substrate/product inhibition in LA production. In contrast, Lee (2005) determined a C:N ratio of 8:1 for LA production $\left(120 \mathrm{~g} \mathrm{l}^{-1}\right)$ from glucose $\left(120 \mathrm{gl}^{-1}\right)$ plus YE $\left(15 \mathrm{~g} \mathrm{l}^{-1}\right)$ with a mixture of five different Lactobacillus spp.

Growth inhibition of the G1 strain was observed at $\mathrm{pH} 3.5$, which agrees with values reported in the literature, which shows that the inhibitory $\mathrm{pH}$ for L. plantarum is 3.2. An increase in $\mathrm{CaCO}_{3}$ concentration of up to $15 \mathrm{~g} \mathrm{l}^{-1}$ prevented drastic $\mathrm{pH}$ decrease and facilitated a better use of lactose. This value is below the concentration reported by Juodeikiene et al. (2016) (20-60 $\left.\mathrm{g} \mathrm{l}^{-1}\right)$ but similar to that reported by Panesar et al. (2010) $\left(15 \mathrm{~g} \mathrm{l}^{-1}\right)$. Thus, $10 \mathrm{~g} \mathrm{l}^{-1}$ of $\mathrm{CaCO}_{3}$ was used because it maintains the conversions obtained by these authors after using $20 \mathrm{~g} \mathrm{l}^{-1}$ of $\mathrm{CaCO}_{3}$.

The low lactose conversion level in whey without YE (36\%) compared with that in MRSM-50 medium with a C:N ratio of $5: 1$, which reached a lactose conversion level of $>90 \%$ (Figure 2D), indicated that it was necessary to add $4 \mathrm{~g} \mathrm{l}^{-1}$ of YE to achieve a satisfactory conversion. This need for protein was also evidenced in the study by Cury Regino et al. (2014), who obtained a LA concentration of $20.8 \mathrm{~g} \mathrm{l}^{-1}$ using whole whey but only of $8.1 \mathrm{~g} \mathrm{l}^{-1}$ using DW medium, which was equal to a conversion of $36.2 \%$. Thus, it appears that supplementation of culture media with $4 \mathrm{~g} \mathrm{l}^{-1}$ of YE is sufficient for attaining a desirable conversion of $70 \%$. This concentration is below that reported by Panesar et al. (2010), i.e. $7.5 \mathrm{gl}^{-1}$, but very similar to the findings reported by Eldeleklioglu et al. (2013), i.e. $4 \mathrm{~g} \mathrm{l}^{-1}$ of YE. The conversion of lactose in the medium containing DW plus YE stabilised at $70 \%$ by the addition of $4 \mathrm{~g} \mathrm{l}^{-1}$ of YE, although this conversion was below that of the reference medium (100\%), possibly because of the inhibitory effect of $\mathrm{pH}\left(\mathrm{Y}_{\mathrm{LA} / \mathrm{Tot}}: 0.84\right)$. It is worth noting that supplementation with $\mathrm{YE}$ is one of the elements that has the greatest impact on the cost of culture media, i.e. accounting for almost 38\% of the cost (Castillo-Martínez et al., 2013); therefore, this is one of the main hurdles in economic LA production by biotechnology.

The biomass concentration attained by the G1 strain in DW medium was $2.5 \mathrm{~g} \mathrm{l}^{-1}$, which is half of what was obtained by Bernardo et al., (2016), i.e. $4.3 \mathrm{gl}^{-1}$ for L. ramnhosus (Bernardo et al., 2016). The maximum specific growth rates of the G1 strain in MRSM-50 and DW media were 0.23 and $0.19 \mathrm{~h}^{-1}$, respectively. Even if these rates are not optimum, they are in the range of 0.2-1.1 $\mathrm{h}^{-1}$, which was reported for lactose-containing culture media (Altiok et al., 2006).

LA yields from lactose $\left(\mathrm{Y}_{\mathrm{P} / \mathrm{S}}\right)$ in MRSM-50 and DW media were 1.2 and $1.05 \mathrm{~g} \mathrm{~g}^{-1}$, respectively; the latter value is much higher than that reported in the literature, which ranges between 0.2 and $0.38 \mathrm{~g} \mathrm{~g}^{-1}$ for this substrate (Hofvendahl \& Hahn-Hägerdal, 2000). The observed $100 \%$ substrate conversion and $\mathrm{Y}_{\mathrm{P} / \mathrm{S}}$ of $1.05 \mathrm{~g} \mathrm{~g}^{-1}$ indicate that the G1 strain has a homofermentative metabolism and is a productive microorganism that yields efficiencies equal to the theoretical maximum value, although there are reports on yields (i.e. $\mathrm{Y}_{\mathrm{P} / \mathrm{S}}$ ) of $1.5 \mathrm{~g} \mathrm{~g}^{-1}$ (Bernardo et al., 2016).

The LA concentration of $56.9 \mathrm{~g} \mathrm{l}^{-1}$ achieved in this study in DW medium containing $49.9 \mathrm{~g} \mathrm{l}^{-1}$ of lactose exceeds the concentration achieved in other studies $\left(36 \mathrm{~g} \mathrm{l}^{-1}\right.$ of LA from a lactose concentration of $57.6 \mathrm{~g} \mathrm{l}^{-1}$ ) (Eldeleklioglu et al., 2013). More recently, Rojas et al. (2015), obtained an LA concentration of $36.7 \mathrm{~g} \mathrm{l}^{-1}$ from a lactose concentration of $47 \mathrm{~g} \mathrm{l}^{-1}$ in whey, resulting in $\mathrm{Y}_{\mathrm{P} / \mathrm{S}}$ of $0.83 \mathrm{~g} \mathrm{~g}^{-1}$. These comparative data demonstrate

Table 3. Lactic acid yields using different bacteria strain and substrate.

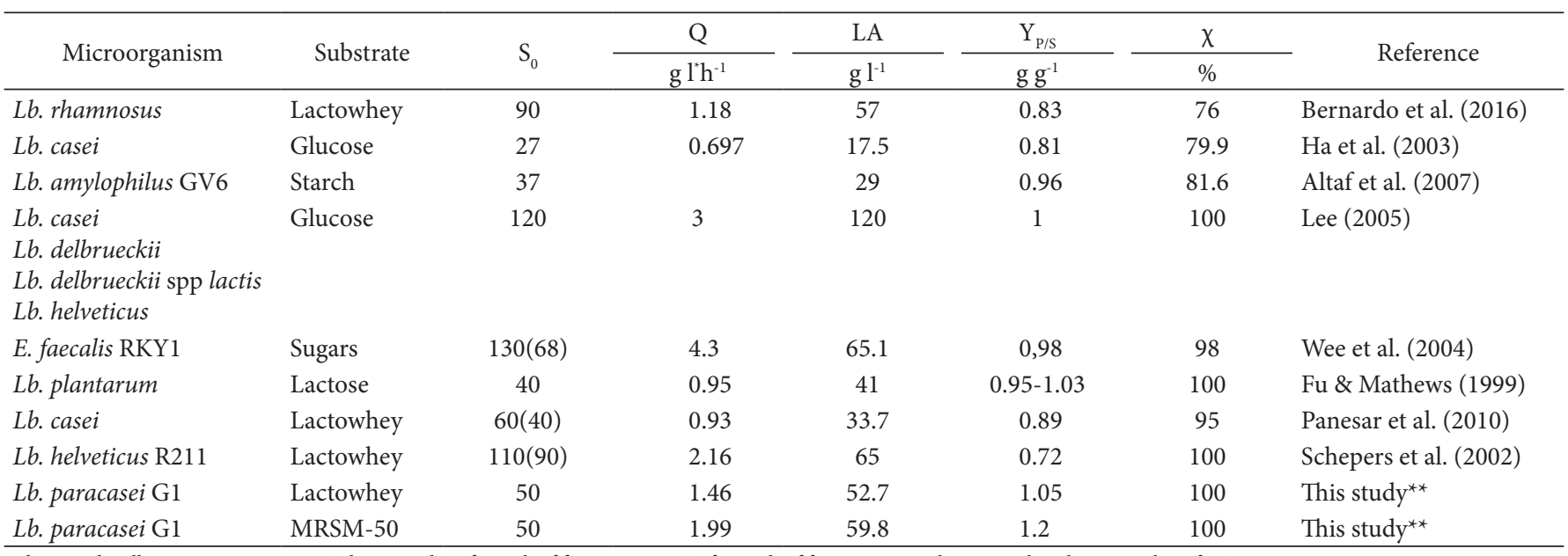

Lb.: Lactobacillus; E.: Enterococcus; LA: lactic acid. *After $36 \mathrm{~h}$ of fermentation; ${ }^{* *}$ after $30 \mathrm{~h}$ of fermentation when it reaches the max value of LA. 
the potential of the G1 strain for the treatment of waste from the dairy industry (Figure 3B).

The LA productivities obtained in the batch system using MRSM-50 and DW media were 1.99 and $1.46 \mathrm{gl}^{-1} \mathrm{~h}^{-1}$, respectively, and these values ranged between 0.7 and $4.3 \mathrm{~g} \mathrm{l}^{-1} \mathrm{~h}^{-1}$ (Table 3 ). Productivity depends on the initial substrate concentration and incubation time in a batch system, requiring their careful comparison (Table 3). The lactose concentration in whey is approximately $50 \mathrm{~g} \mathrm{l}^{-1}$, which does not limit LA production as a result of substrate inhibition because that only occurs at concentrations $>100 \mathrm{gl}^{-1}$ (Kim et al., 2006). The $100 \%$ conversion attained in this study confirms that no lactose inhibition occurs during fermentation in whey.

\section{Conclusions}

A Lactobacillus strain named G1 was isolated, which was later identified as L. paracasei paracasei. This isolate was cultured in DW supplemented with YE $\left(4 \mathrm{~g} \mathrm{l}^{-1}\right)$ and reached $\mathrm{Y}_{\mathrm{P} / \mathrm{S}}$ of $1.05 \mathrm{~g} \mathrm{~g}^{-1}$. In batch production, the performance of the G1 strain was $1.46 \mathrm{~g}(\mathrm{~L} \mathrm{~h})^{-1}$, whereas in continuous production, its performance was $2.99 \mathrm{~g}(\mathrm{~L} \mathrm{~h})^{-1}$. The low EL requirements and $100 \%$ conversion of lactose in whey contribute to the cost-effective nature of this process. This promising strain could become a viable option for the treatment of dairy industry residues, while not only meeting the disposal requirements but also increasing profits with LA as a by-product.

\section{Acknowledgements}

This work was partially supported by a sustainable grant (Biotransformation Group) from Universidad de Antioquia.

\section{References}

Abdel-Rahman, M. A., Tashiro, Y., \& Sonomoto, K. (2013). Recent advances in lactic acid production by microbial fermentation processes. Biotechnology Advances, 31(6), 877-902. http://dx.doi. org/10.1016/j.biotechadv.2013.04.002. PMid:23624242.

Adamberg, K., Kask, S., Laht, T. M., \& Paalme, T. (2003). The effect of temperature and $\mathrm{pH}$ on the growth of lactic acid bacteria: a $\mathrm{pH}$-auxostat study. International Journal of Food Microbiology, 85(1-2), 171-183. http://dx.doi.org/10.1016/S0168-1605(02)00537-8. PMid:12810281.

Altaf, M., Venkateshwar, M., Srijana, M., \& Reddy, G. (2007). An economic approach for L-(+) lactic acid fermentation by Lactobacillus amylophilus GV6 using inexpensive carbon and nitrogen sources. Journal of Applied Microbiology, 103(2), 372-380. http://dx.doi. org/10.1111/j.1365-2672.2006.03254.x. PMid:17650197.

Altiok, D., Tokatli, F., \& Harsa, S. (2006). Kinetic modelling of lactic acid production from whey by Lactobacillus casei (NRRL B-441). Journal of Chemical Technology and Biotechnology (Oxford, Oxfordshire), 81(7), 1190-1197. http://dx.doi.org/10.1002/jctb.1512.

Alves de Oliveira, R., Komesu, A., Vaz Rossell, C. E., \& Maciel, R. Fo. (2018). Challenges and opportunities in lactic acid bioprocess design - From economic to production aspects. Biochemical Engineering Journal, 133, 219-239. http://dx.doi.org/10.1016/j.bej.2018.03.003.

Axelsson, L. (2004). Lactic acid bacteria: classification and physiology. lactic acid bacteria: microbiological and functional aspects. In S. Salminen \& A. Y. Wright. Title. Nova York: Marcel-Dekker.
Bailey, J. E., \& Ollis, D. F. (1986). Biochemical engineering fundamentals (McGraw-Hill Chemical Engineering Series, pp. 983). Nova York: McGraw-Hill.

Bernardo, M. P., Coelho, L. F., Sass, D. C., \& Contiero, J. (2016). 1-(+)Lactic acid production by Lactobacillus rhamnosus B103 from dairy industry waste. Brazilian Journal of Microbiology, 47(3), 640-646. http://dx.doi.org/10.1016/j.bjm.2015.12.001. PMid:27266630.

Castillo-Martínez, F. A., Balciunas, E. M., Salgado, J. M., Domínguez González, J. M., Converti, A., \& Oliveira, R. P. S. (2013). Lactic acid properties, applications and production: A review. Trends in Food Science \& Technology, 30(1), 70-83. http://dx.doi.org/10.1016/j. tifs.2012.11.007.

Cury Regino, K., Arteaga Márquez, M., Martínez Flórez, G., Luján Rhenals, D., \& Durango Villadiego, A. (2014). Evaluación de la fermentación del lactosuero ácido (entero y desproteinizado) utilizando Lactobacillus casei. Revista Colombiana de Biotecnologia, 16(1), 137-145. http://dx.doi.org/10.15446/rev.colomb.biote.v16n1.44281.

De Giori, G. S., de Valdez, G. F., de Ruiz Holgado, A. P., \& Oliver, G. (1985). Effect of $\mathrm{pH}$ and temperature on the proteolytic activity of lactic acid bacteria. Journal of Dairy Science, 68(9), 2160-2164. http://dx.doi.org/10.3168/jds.S0022-0302(85)81085-7.

Eldeleklioglu, B., Bayraktar, E., \& Mehmetoglu, U. (2013). The effects of nutrient supplements on the production of lactic acid from cheese whey. Turkish Journal of Biochemistry, 38, 81-91. http://dx.doi. org/10.5505/tjb.2013.46036.

Fu, W., \& Mathews, A. P. (1999). Lactic acid production from lactose by Lactobacillus plantarum: kinetic model and effects of $\mathrm{pH}$, substrate, and oxygen. Biochemical Engineering Journal, 3(3), 163-170. http:// dx.doi.org/10.1016/S1369-703X(99)00014-5.

Gänzle, M. G. (2015). Lactic metabolism revisited: metabolism of lactic acid bacteria in food fermentations and food spoilage. Current Opinion in Food Science, 2, 106-117. http://dx.doi.org/10.1016/j. cofs.2015.03.001.

Garrity, G. M., Boone, D. R., \& Castenholz, R. W. (2001). Bergey's manual of systematic bacteriology (Vol. 1). New York: Springer.

González, M. I., Álvarez, S., Riera, F., \& Álvarez, R. (2007). Economic evaluation of an integrated process for lactic acid production from ultrafiltered whey. Journal of Food Engineering, 80(2), 553-561. http://dx.doi.org/10.1016/j.jfoodeng.2006.06.021.

Grand View Research. (2017). Lactic acid market analysis by application and segment forecasts, 2018-2025. San Francisco: Grand View Research.

Ha, M.-Y., Kim, S.-W., Lee, Y.-W., Kim, S.-J., \& Kim, S. J. (2003). Kinetic analysis of growth and lactic acid production in $\mathrm{pH}$ - controlled batch cultures of Lactobacillus casei KH-1 using yeast extract/corn steep liquor/glucose medium. Journal of Bioscience and Bioengineering, 96(2), 134-140. http://dx.doi.org/10.1016/S1389-1723(03)90115-0. PMid:16233498.

Hofvendahl, K., \& Hahn-Hägerdal, B. (2000). Factors affecting the fermentative lactic acid production from renewable resources. Enzyme and Microbial Technology, 26(2-4), 87-107. http://dx.doi. org/10.1016/S0141-0229(99)00155-6. PMid:10689064.

Juodeikiene, G., Zadeike, D., Bartkiene, E., \& Klupsaite, D. (2016). Application of acid tolerant Pedioccocus strains for increasing the sustainability of lactic acid production from cheese whey. Lebensmittel-Wissenschaft + Technologie, 72, 399-406. http://dx.doi. org/10.1016/j.lwt.2016.05.023.

Kim, H.-O., Wee, Y.-J., Kim, J.-N., Yun, J.-S., \& Ryu, H.-W. (2006). Production of lactic acid from cheese whey by batch and repeated batch cultures of Lactobacillus sp. RKY2. Applied Biochemistry 
and Biotechnology, 131(1-3), 694-704. http://dx.doi.org/10.1385/ ABAB:131:1:694. PMid:18563646.

Kozlovskiy, R., Shvets, V., \& Kuznetsov, A. (2017). Technological aspects of the production of biodegradable polymers and other chemicals from renewable sources using lactic acid. Journal of Cleaner Production Sustainable Development of Energy. Water and Environmental Systems, 155, 157-163. http://dx.doi.org/10.1016/j. jclepro.2016.08.092.

Lee, K. (2005). A media design program for lactic acid production coupled with extraction by electrodialysis. Bioresource Technology, 96(13), 1505-1510. http://dx.doi.org/10.1016/j.biortech.2004.11.010. PMid:15939279.

Luedeking, R., \& Piret, E. L. (1959). A kinetic study of the lactic acid fermentation. Batch process at controlled $\mathrm{pH}$. Reprinted from Journal of Biochemical and Microbiological Technology Engineering Vol. I, No. 4. Pages 393-412 (1959). Biotechnology and Bioengineering, 1, 13931412. http://dx.doi.org/10.1002/jbmte.390010406. PMid:10699846.

Mollea, C., Marmo, L., \& Bosco, F. (2013). Valorisation of cheese whey, a by-product from thedairy industry. London: INTECH. http:// dx.doi.org/10.5772/53159.

Monod, J. (1949). The growth of bacterial culture. Annual Review of Microbiology, 3(1), 371-394. http://dx.doi.org/10.1146/annurev. mi.03.100149.002103.

Panesar, P. S., Kennedy, J. F., Knill, C. J., \& Kosseva, M. (2010). Production of L(+) lactic acid using Lactobacillus casei from whey. Brazilian Archives of Biology and Technology, 53(1), 219-226. http://dx.doi. org/10.1590/S1516-89132010000100027.

Rojas, A. M., Montaño, L. P., \& Bastidas, M. J. (2015). Producción de ácido láctico a partir del lactosuero utilizando Lactobacillus delbrueckii subsp. bulgaricus y Streptococcus thermophilus. Revista
Colombiana de Quimica, 44(3), 5-10. http://dx.doi.org/10.15446/ rev.colomb.quim.v44n3.55604.

Schepers, A. W., Thibault, J., \& Lacroix, C. (2002). Lactobacillus helveticus growth and lactic acid production during $\mathrm{pH}$-controlled batch cultures in whey permeate/yeast extract medium. Part I. multiple factor kinetic analysis. Enzyme and Microbial Technology, 30(2), 176-186. http://dx.doi.org/10.1016/S0141-0229(01)00465-3.

Stiles, M. E., \& Holzapfel, W. H. (1997). Lactic acid bacteria of foods and their current taxonomy. International Journal of Food Microbiology, 36(1), 1-29. http://dx.doi.org/10.1016/S0168-1605(96)01233-0. PMid:9168311.

Wang, Y., Tashiro, Y., \& Sonomoto, K. (2015). Fermentative production of lactic acid from renewable materials: Recent achievements, prospects, and limits. Journal of Bioscience and Bioengineering, 119(1), 10-18. http://dx.doi.org/10.1016/j.jbiosc.2014.06.003. PMid:25077706.

Wee, Y.-J., Kim, J.-N., Yun, J.-S., \& Ryu, H.-W. (2004). Utilization of sugar molasses for economical L(+)-lactic acid production by batch fermentation of Enterococcus faecalis. Enzyme and Microbial Technology, 35(6-7), 568-573. http://dx.doi.org/10.1016/j. enzmictec.2004.08.008.

You, S., Chang, H., Yin, Q., Qi, W., Wang, M., Su, R., \& He, Z. (2017). Utilization of whey powder as substrate for low-cost preparation of $\beta$-galactosidase as main product, and ethanol as by-product, by a litre-scale integrated process. Bioresource Technology, 245(Pt A), 1271-1276. http://dx.doi.org/10.1016/j.biortech.2017.08.092.

Zuñiga, M., Pardo, I., \& Ferrer, S. (1993). An improved medium for distinguishing between homofermentative and heterofermentative lactic acid bacteria. International Journal of Food Microbiology, 18(1), 37-42. http://dx.doi.org/10.1016/0168-1605(93)90005-2. PMid:8466811. 